Kıvrak, Z. ve Yıldırım, K. (2020). Öğretmenlerin gözünden birinci sınıf öğrencilerin okuma ve yazma becerilerini öğrenim süreçlerine ailelerin katılımı. Ana Dili Eğitimi Dergisi, 8(2), 447-468.

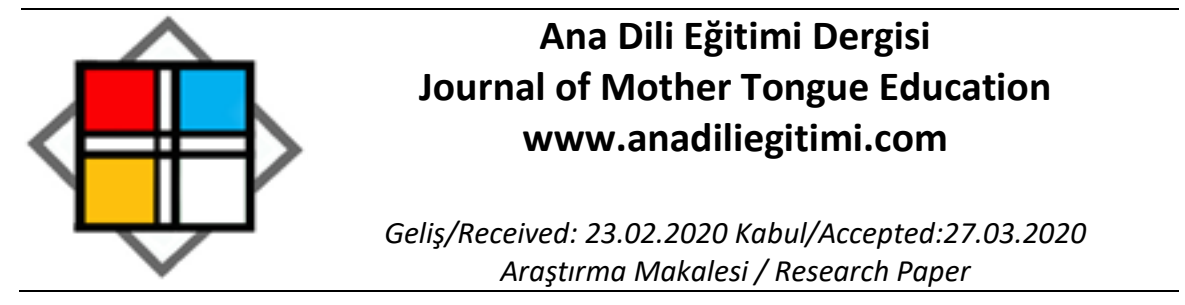

\title{
Öğretmenlerin Gözünden İlkokul Birinci Sınıf Öğrencilerin Okuma Yazma Becerilerini Öğrenme Süreçlerine Ailelerin Katılımı*
}

\author{
Zehra KIVRAK ${ }^{* *}$ \\ KasIm YILDIRIM***
}

\begin{abstract}
Öz
Bu araştırma, ilkokul birinci sınıf öğrencilerinin ilk okuma ve yazma becerilerinin öğrenim süreçlerine aile katııımının etkisinin birinci sınıf öğretmenleri gözünden değerlendirmeyi amaçlayan nitel bir durum araştırması olarak gerçekleştirilmiştir. Çalışmaya Kars ilinde görev yapmakta olan 43 birinci sınıf öğretmeni katılmıştır. Araştırmacılar tarafından geliştirilmiş açık uçlu sorulardan oluşan anket formu ölçme aracı olarak kullanılmıştır. Elde edilen veriler üzerinden betimsel analizler gerçekleştirilmiştir. Araştırmanın bulgularından elde edilen sonuçlarda aile katııımının yetersiz olduğu görülmüştür. Aile katılımının sağlanmasına yönelik yapılan çalışmaların aileler üzerindeki etkisinin yetersiz kaldığına dair görüşlere ulaşılmıştır. Aile katııımının yetersiz kalmasının en büyük etkisi olarak ailelerin beklentilerinin, önceliklerinin olduğu görülmüştür. Aile desteği gören öğrencilerin ise sınıftaki diğer arkadaşları ile arasında olan farklılıkların gözle görülür bir şekilde olduğu anlaşılmıştır. Bu bulgular yanında ilk okuma ve yazma sürecinin okul ile sınırlı kalmaması, evde de aile tarafından gerekli desteğin verilmesinin daha yararlı olduğu konusunda görüş birliği olduğu anlaşılmıştır.
\end{abstract}

Anahtar Kelimeler: Okuma ve yazma öğretimi, aile katılımı, sınıf öğretmenleri

\section{Effects of Parent Involvement in First-Grade Students' Learning Reading and Writing: Views of Elementary School Classroom Teachers}

\begin{abstract}
The research was used qualitative case study in order to evaluate the effect of parent involvement in the first graders' learning reading and writing skills from the views of elementary school classroom teachers. A total of 43 first grade teachers working in Kars province participated in the study. The questionnaire consisting of open-ended questions formed by the researchers was used as a measurement tool. Descriptive analysis was employed on the obtained data. It was seen that family involvement was insufficient according to results obtained from findings of the research. It was found that the effect of the studies on family involvement was insufficient for the families. Expectations and priorities of parents were seen as the biggest effect of insufficient family involvement. It was observed that the differences between the students having family support and the other friends in the class were noticeable. It was come into agreement that first reading and writing process is not limited to school and it will be more useful to continue and integrate at home Keywords: Teaching reading and writing, parent involvement, elementary school classroom teachers
\end{abstract}

\footnotetext{
${ }^{*}$ Bu makale Zehra Kıvrak tarafından hazırlanan yüksek lisans tezinden üretilmiştir.

** Öğretmen, Muğla Sıtkı Koçman Üniversitesi, Eğitim Fakültesi, Temel Eğitim Bölümü, Muğla, cinarzehra11@gmail.com, ORCID: 0000-0003-1406-709X

*** Dr., Muğla Sıtkı Koçman Üniversitesi, Eğitim Fakültesi, Temel Eğitim Bölümü, Muğla, dogukanepsilon@gmail.com, ORCID: 0000-0003-1406-709X
} 


\section{Giriş}

Okuma ve yazma becerileri bireyin kendini gerçekleştirmesini ve dolayısıyla toplumun sürekliliğini sağlayan temel yaşam becerilerinden biridir (Tok, Tok ve Mazı, 2008). Okuma ve yazma becerileri ile sıklıkla aynı anlamda kullanılan "okuryazarlık" sözlü ve yazılı iletişim sistemlerinin etkili bir şekilde kullanılabilmesi için önemli bir araçtır (Gül, 2007). Erken çocukluk döneminde okuryazarlığın temelleri atılmakta ve ilkokul yaşantısının başlaması ile birlikte okuma ve yazma becerileri elde edilmektedir.

Günümüzde donanımlı bir birey olmak giderek önem arz etmektedir. Bu özelliklere sahip olabilmek için pek çok beceriye intiyaç duyulmaktadır. Bu beceriler; bireyin kişisel potansiyeline, bulunduğu sosyal çevreye ve içinde bulunduğu birtakım imkânlara bağlı olabilmektedir. İşte bu noktada kişinin pek çok şeyden en etkin biçimde faydalanabilmesi işlevsel okuryazar olmasını gerekli kılar. Bu yüzden işlevsel okuryazarlık, kişinin hayatına çocukluktan itibaren yerleşebilmelidir. Bunun için de öncelikle ailenin; çocuğun hayatının her safhasında işlevsel okuryazarlığa yer vermesi ve çocuğu desteklemesi gerekmektedir (Özenç, 2012).

Öğrenme-öğretme sürecine ilişkin olarak okul başarısını arttıran faktörler üzerinde yapılan araştırmalar, okul başarısı üzerinde okul-aile dayanışmasının önemli bir etkiye sahip olduğunu göstermektedir (Çelenk, 2003).

Anne-babalar sadece öğrencilerin ilk öğretmenleri değil aynı zamanda da eğitimcilerin ortaklarıdır. Anne-babaların çocuklarıyla ilgili bir anlayışları vardır ve bu anlayış öğretmenler için öğrenme deneyimlerini planlarken değerli olabilmektedir. Benzer şekilde öğretmenler de öğrencileri, anne-babalardan farklı bir şekilde, farklı ortamda tanıdıkları için anne-babaların çocuklarını tanımalarına katkıda bulunabilmektedirler. Eğitimcilerin, anne-babaları öğretim programı ve çocuklarının ilerlemeleri hakkında bilgilendirme sorumlulukları vardır. Bunun yanında anne-babalar da okul programına ve hedeflerine katkıda bulunabilirler. Anne-babalar çocuklarını güdülemede, okulda öğrenilenler ile dışarıdaki fırsatlar arasında bağlantı kurmada aktif rol üstlenebilirler (Danielson, 2002, akt. Keçeli-Kaysılı, 2008).

Çocuğun ilkokula başlamasıyla birlikte, öğrencinin okul başarısı üzerinde rol oynayan çevresel etkiler toplumun daha yeni bir kesimine doğru genişler. Fakat aile etkisi bütünüyle ortadan kalkmaz. Günün 24 saati içerisinde okul saatlerin miktarı göz önüne alınırsa, çocuk yaşamının 3/4'nün bu dönemde de aile içerisinde geçirir. Bu durum, okul yıllarında da çocuk- aile etkileşiminin önemini göstermektedir (Çelenk, 2003).

Illk okuma ve yazma öğretiminde, evde çocuğuna eğitim yardımı sağlayan ve bu amaçla okul ile yakın işbirliğine giren ailelerin çocuklarının okuduğunu anlama başarılarının daha yüksek olduğu sonucuna varılmıştır (Çelenk, 2003).

Okulda yapılan eğitim evde anne-babalar tarafından da desteklenmediği sürece, okul eğitiminde başarıya ulaşmak olası değildir. Okul ve aile iki farklı toplumsal kurumdur ve farklı beklentiler etrafında şekillenmişlerdir. Bu iki farklı kurumun çocukların eğitimleri konusunda çıkar birliğine getirilmesi gereklidir. Sorun özellikle okul eğitiminin başlangıcı olan ilköğretim birinci sınıflar için çok daha önemlidir; çünkü en temel çalışma ve öğrenme becerileri bu yılda oluşturulmaktadır (Şimşek ve Tanaydın, 2002).

Aile içi uyum, ailenin destekleyici yaklaşımı ve ailenin okul etkinliklerine katılmasındaki çeşitliliğin, okul başarısı üzerinde önemli etkileri vardır. Yapılan araştırmalarda sınıf içerisindeki başarısı düşük öğrencileri diğer öğrencilerden ayıran en önemli etkenin anne-baba ilgisi olduğu belirlenmiştir. Aynı zamanda anne-babanın çocuklarına olan otoritesi ve tutarsızlığı da akademik başarısında önemli rol oynadığı görülmüştür (Çelenk, 2003).

Aile katılımının sağlanabilmesi için eğitimciler okul-aile işbirliğine inanmalı ve planlamalarını bu doğrultuda yapmalıdır. Eğitimciler, ailelere okulda verilen eğitimi desteklemeleri gerektiğini ve bu şekilde çocuklarının başarıyı elde edebileceklerini anlatmalıdır. Bu sebeple çocuklar okula başladığı andan itibaren eğitimciler ile aileler iletişim halinde olmalıdır. Çocukların başarılı olabilmesi için okulaile-toplum işbirliği önem göstermektedir (Oğuz, 2012).

Okul-aile iş birliği süreci, ailelerin çocuklarını okula kayıtlarını yaptırdıkları ilk andan itibaren başlamaktadır. Böylece öğretmenlerin aile katılımı programı felsefelerini belirledikten sonra ellerinde, 
kayıtlar sırasında edinilen çocuk ve aileye ilişkin temel bilgiler mevcut olmaktadır. Çocuklar ve aileler ile ilgili elde edilen bu ilk bilgiler, aile katılımı programının genel çerçevesini oluşturmaktadır (Ömeroğlu ve Yaşar, 2005).

Okulda verilen eğitimin evde, evde verilen eğitimin okulda desteklenmesiyle bir devamlılığın olması ve böylece hem okulda hem de evde çocuğun istendik davranış değişikliklerine doğru bir biçimde ulaşması sağlanacaktır. Okul ve aile iş birliği öğrenci başarısını arttıırken, katılım, güdüleme, kendine güven ve olumlu davranışların gelişmesinde oldukça etkilidir. Çocukların okul ve öğretmene karşı olumlu tutum geliştirmesinde aile katılımı temel araç olarak görülmektedir (Güler, 2007).

Akademik ve sosyal gelişim özellikleri açısından bakıldığında, ilkokul birinci sınıf öğretim etkinlikleri içerisinde yer alan ilk okuma yazma süreci, temel ve zorunlu öğrenim basamağını oluşturan ilköğretimin en önemli aşamalarından biridir. Bu aşamanın öğrencinin öğrenim yaşantılarına başarılı bir başlangıç görevi görebilmesi için etkili bir yaklaşımla yönetilmesi gerekir. Bu amaçla yapılacak en önemli yönetsel etkinliklerden biri, "ilk okuma yazma öğretimi sürecine aile desteğinin sağlanmasıdır." Bu sebeple, öncelikle her aile için "aile eğitimi intiyaç analizi" yapılması gerekir. Çünkü ailelerin eğitsel açıdan sahip oldukları avantajı veya dezavantajlı durumların neler olduğu bilinmeden çocuklarının eğitimine sağlayabilecekleri etkili destekleri bilinemez. İlköğrenimin başlangıcını oluşturan "ilk okuma yazma süreci" ilk, orta ve yükseköğrenimin de temelini oluşturmaktadır. Illk okuma yazma süreci, işlevsel okuryazarlığın yanında tüm öğretimsel yaşantıların başlangıcını oluşturan yeterliklerin kazandırılmaya çalışıldığı bir aşamadır. Illk okuma yazma sürecinin başarısı, aile ile okulun tam ve sürekli işbirliğine dayalıdır. Çocukları ilköğretime yeni başlayan aileler, bir yandan çocuklarının okullarına tam zamanlı katııımını sağlamak, diğer yandan okul yaşantıları içinde yer alan eğitsel ve sosyal etkinliklere sürekli katılımda bulunmak durumundadır. Okula etkili aile katıımı, okulların öğrenci özellik ve gereksinimlerine uygun olarak ailelere sunacağı "aile eğitimi" sayesinde sağlanabilir (Özbaş, 2013).

Bu araştırmada da aile katıımının birinci sınıf öğrencilerin okuma ve yazma becerini öğrenme süreçlerine etkileri sınıf öğretmenleri görüşleri doğrultusunda değerlendirilmesi amaçlanmıştır. Bu amaç doğrultusunda aşağıdaki sorulara cevaplar aranmıştır:

1. Okuma ve yazma becerilerini kazanım sürecinde aile katılımının etkisi nedir?

2. Aileler çocuklarının okuma ve yazma becerilerini öğrenme süreçlerine hangi yollarla dahil olabilirler.

3. Okul ve öğretmen aile katılım sürecini nasıl kolaylaştırabilirler?

4. Aile katılımı noktasında öğretmenlerin karşılaştıkları güçlükler nelerdir?

\section{Araştırmanın Modeli}

\section{Yöntem}

Bu araştırmada ilkokul birinci sınıf öğrencilerinin okuma yazma becerilerini kazanmalarında öğrenme süreçlerine etkin aile katılımının sınıf öğretmenlerinin gözünden değerlendirilmesi amaçlanmıştır. Bu bağlamda araştırma nitel bir durum araştırması olarak desenlemiştir. Araştırmada amaca uygun olarak nitel araştırma yöntemlerinden olgu bilim (fenomonoloji) kullanılmıştır.

Nitel araştırmalar olay, olgu ve durumların olduğu gibi ortaya konmasını ve nedenlerinin belirlenmesini sağladığı gibi katılımcıların bizzat sürece dâhil olmalarını sağlaması bakımından da önemli bir araştırma desenidir (Özcan ve Özcan, 2016).

\section{Araştırma grubu}

Çalışma grubunu Kars ilinde görev yapmakta olan 43 sınıf öğretmeni oluşturmuştur. Tez çalışmasında kolay ulaşılabilir örneklem yönteminden faydalanılmıştır. Çalışmaya katıım gönüllülük esası üzerine kurulmuştur. Çalışma kapsamında 60 sınıf öğretmeni ile iletişime geçilmiştir. Ancak 60 sınıf öğretmeninden sadece 43 sınıf öğretmeni anketlere geri dönüş sağlamıştır. Araştırmayı oluşturan katılımcıların yaklaşık \%67'sini kadın öğretmenlerin, yaklaşık \%33'ünü ise erkek öğretmenlerin oluşturmuştur. Katılımcıların yaş özelliğine göre 20-30 yaş aralığındaki katılımcılar yaklaşık \%79'luk, 3040 yaş aralığındaki katılımcılar yaklaşık \%13, 40 yaş ve üstü katılımcılar ise yaklaşık $\% 8^{\prime}$ lik bir dilim oluşturmuştur. Mesleki deneyim özelliğine göre ise 1 ay-10 yıl kategorisini katılımcıların yaklaşık \%88'lik, 11 yıl-20 yıl kategorisini katılımcıların yaklaşık \%5'lik, 21 yıl-30 yıl kategorisini katılımcıların 
yaklaşık \%2'lik, 31 yıl ve üstü kategorisini katılımcıların yaklaşık \%5'lik kısmın oluşturduğu görülmüştür. Görev yeri özelliği göz önüne alındığında katılımcılar arasından köyde çalışan öğretmenler yaklaşık \%74, ilçede çalışan öğretmenler yaklaşık \%21, ilde çalışan öğretmenler yaklaşık \%5'lik bölümünü oluşturmaktadır. Kurumdaki görev süresi özelliği dikkate alındığında ise 1 ay-10 yıl kategorisini \%98'lik, 11 yıl-20 yıl kategorisini \%2'lik dilimin oluşturduğu görülmektedir. Meslek hayatları boyunca okuttukları sınıf düzeyleri özelliği incelendiğinde ise katılımcıların yaklaşık \%91'i 1. sınıf, katılımcıların yaklaşık \%60' 2 . sınıf, katılımcıların yaklaşık \%53'ü 3. sınıf, katılımcıların yaklaşık \%63'ü 4 . sınıf okuttuğu görülmüştür.

\section{Veri Toplama Araçları}

Çalışmada araştırmacılar tarafından geliştirilen açık uçlu sorulardan oluşmuş anket formu kullanılmıştır. Anketin geliştirme sürecinde ilgili literatür incelenmiş ve elde edilen bilgiler doğrultusunda hazırlanan sorularla taslak bir form yapılandırımıştır. Oluşturulan taslak form, araştırmacıların da dâhil olduğu uzmanlar tarafından incelenmiştir. Illgili dönütlerin yapılması ile birlikte soruların ölçülmek isteneni ölçme, araştırmanın amacına hizmet etme, anlaşılma, sıralanma ve tasarım açısından yeniden düzenlenmiştir. Ardından araştırma grubu dışındaki 5 sınıf öğretmenine anket formu verilerek onlardan gelen dönütler ile anket formu yeniden düzenlenmiştir. Anket formu beş bölümden oluşmuştur. Illk bölümde katılımcıların demografik özelliklerine ilişkin sorular yer almıştır. Bu bölümdeki sorular ile katılımcıların cinsiyet, yaş, mesleki deneyim, çalıştığı okulun bulunduğu yer, çalıştığı okuldaki görev süresi ve bugüne kadar okuttuğu sınıf düzeylerine ilişkin veriler toplanmıştır. Anketin ikinci bölümünde ise katılımcıların ön yaşantılarına ait veriler toplanmıştır. Bu bölümde toplamda 5 açık uçlu soruya yer verilmiştir. Anketin üçüncü bölümünde ise katılımcıların aile katılımına yönelik uyguladıkları planlamalara, okulun uyguladığı planlamalara, velilerin aile katılımına yönelik çalışmalarına yönelik kişisel stratejileri ve deneyimlerine ilişkin görüşleri hakkındaki veriler toplanmıştır. Bu bağlamda anketin üçüncü bölümünde toplam 16 açık uçlu soru yer almıştır. Anketin dördüncü bölümünde ise katııımcıların aile, aile katııımı ve çalıştığı kurum ile ilgili inançlarına yönelik görüşleri hakkında veriler toplanmıştır. Bu bölümde toplamda 13 açık uçlu soruya yer verilmiştir. Anketin son bölümü olan beşinci bölümde ise katılımcıların ailelerin etkin katılımına yönelik meslektaşlarına önerdikleri tavsiyelere yönelik görüşlerine ilişkin veriler toplanmıştır. Bu bağlamda anketin son bölümü olan kapanış bölümünde toplamda 1 açık uçlu soruya yer verilmiştir.

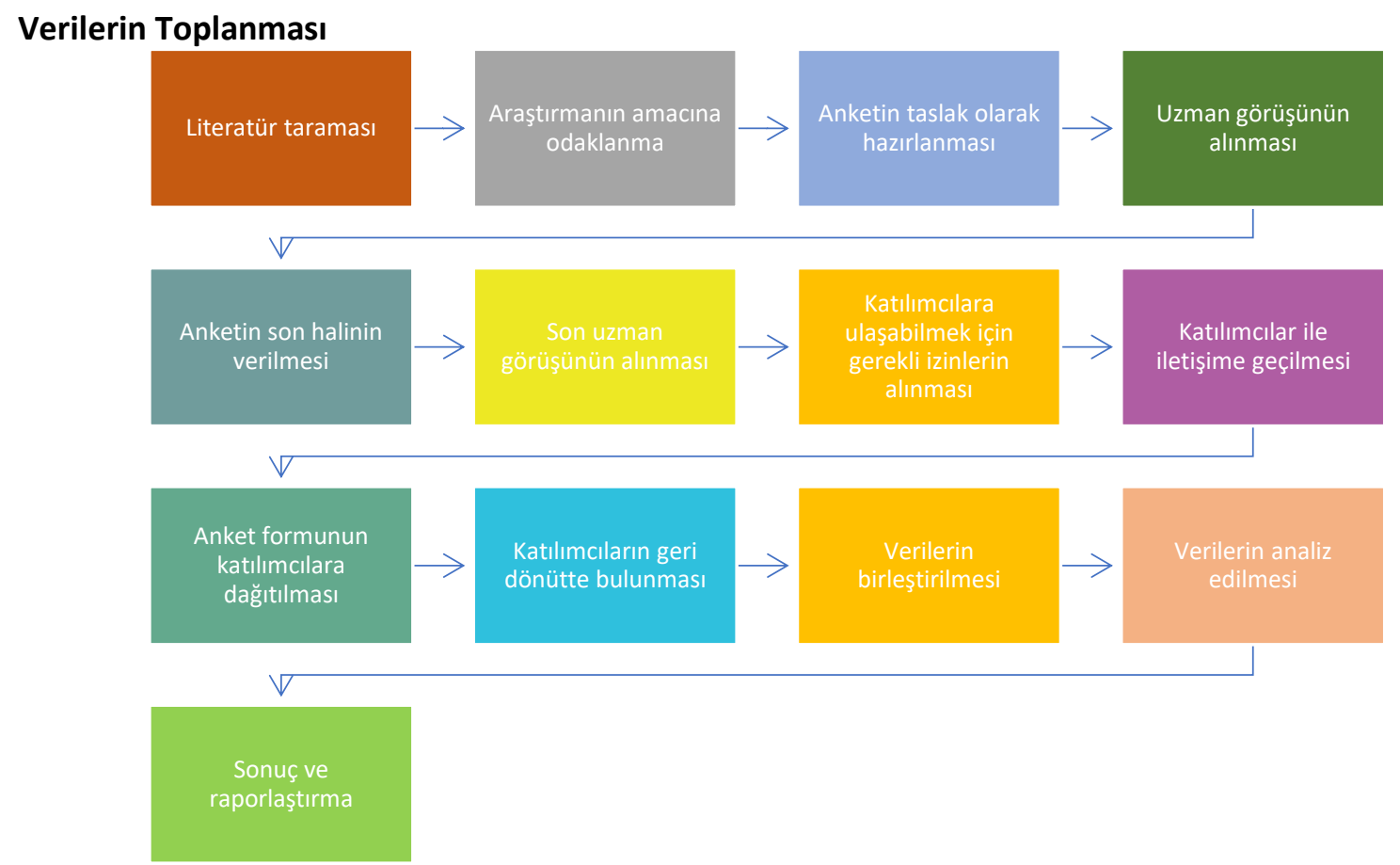

Şekil 1. Veri toplama süreci 
Şekil 1'de görüldüğü üzere literatürün taranması sonucunda araştırmanın amacına uygun anket hazırlanmıştır. Uzman görüşleri alınarak anket üzerinde gerekli düzeltmeler yapılmıştır. Gerekli izinlerin Kars İ Milli Eğitim Müdürlüğünden alınması ile birlikte izin süreci tamamlanmıştır. Katılımcılar ile iletişime geçilmek istendiğinde ise bazı sıkıntılar ortaya çıkmıştır. Çevre şartlarından, ulaşımdan ve görev yapıldığı yerin çok küçük bir ilçe olmasından kaynaklı katılımcılara ulaşmada sıkıntılar oluşmuştur. Bu tür sıkıntılardan dolayı sadece 60 katılımcı ile iletişime geçilebilmiştir. Ancak bu katılımcılar ise anket doldurma sürecini uzatmış ve sadece $43 \mathrm{katılımcı} \mathrm{geri} \mathrm{dönütte} \mathrm{bulunmuştur.} \mathrm{Verilerin} \mathrm{toplanması} \mathrm{süreci}$ tüm bu olumsuzlukların sonucunda uzamıştır. Planlanan süreçten daha uzun bir süreçte tamamlanmıştır. Verilerin bir araya getirilmesi ile birlikte analiz süreci başlamıştır.

\section{Verilerin Analizi}

Açık uçlu sorudan elde edilen veriler öncelikli olarak her bir soru başlığı altında bilgisayarda WORD ortamına aktarıımış ve her bir araştırmacı tarafından ayrı ayrı analiz edilmiştir. Daha sonra ulaşılan kodlamalar karşılaştırılmıştır. Görüş farklılıklarının olduğu durumlarda sonuçlar birlikte yeniden değerlendirilmiş ve uzlaşma sağlanmıştır. Elde edilen kodlar tekrarlanma sıklıkları doğrultusunda ilgili oldukları soru başlığı altında tablolaştırılarak sunulmuştur. Tablolardaki frekans değerleri kişi sayısını değil, yapılan kodlamanın kaç kişi tarafından ifade edildiğini göstermiştir.

\section{Geçerlik ve Güvenirlik}

Nitel paradigma mantığının benimsendiği çalışmalarda araştırma bulgularının sayısal niceliklerle de desteklenmesi araştırmaların kalitesini artırmada kullanılan önemli yollardan biridir (Yıldırım, 2010). Bu araştırmada da elde edilen veriler sayısal değerlerle desteklenmiştir. Araştırmada elde edilen veriler çalışmadaki araştırmacılar tarafından değerlendirilmiş ve sürekli yapılan karşılaştırmalarla en doğru yargılara ulaşılmaya çalışılmıştır. Daha sonra veriler araştırmanın mantığını bilen, eğitim programları alanında çalışan bağımsız bir kodlayıcıya verilmiş ve kendisinden verileri değerlendirmesi istenmiştir. Daha sonra bağımsız araştırmacının ulaştığı değerlendirmeler ile araştırmacıların ulaşmış oldukları sonuçlar karşılaştııılmış ve var olan uyuşmazlıklar giderilmeye çalışılmıştır. Araştırmacıların ve bağımsız kodlayıcının ikilemde kaldığı durumlar tekrar gözden geçirilmiş ve ortak bir fikir birliğine varılıncaya kadar gerekli düzeltmeler gerçekleştirilmiştir. Yapılan bu araştırmanın transfer edilebilirliğini artırmak için anlaşıır ve detaylı betimlemelere yer verilmiş; veri toplama süreci, katılımcıların özellikleri, nasıl seçildikleri ve veri analiz süreci detaylı bir şekilde araştırmada sunulmuştur. Bu şekilde araştırmanın transfer edilebilirliğine katkı sağlanmıştır (Creswell ve Miller, 2000). Bu şekilde yapılacak benzer çalışmalara ayrıntılı betimlemeler vasıtası ile yol gösterilmiştir. Bu araştırmada çalışmanın geçerliğini ve güvenirliğini artırmak için izlenilen yollardan biri de ulaşılan sonuçların çalışmadaki katılımcılardan bazılarına gösterilmesi ve ulaşılan sonuçlar hakkında onların görüşlerinin alınmasıdır. Böylelikle elde edilen bulgulara yönelik katılımcılardan dönütler alınmış ve bu şekilde araştırmacılardan kaynaklanabilecek yanlılıklar en aza indirgenmeye çalışı ımışır. Elde edilen bulguların inandırıcılığını artırmak amacı ile katılımcıların açık uçlu sorulara ilişkin belirtmiş oldukları görüşlerden örnek alıntılara yer verilmiştir. Bu alıntılar yapılırken araştırmaya yanlıık katacak görüşler değil, verilen cevapların genelini yansıtacak görüşlerle ilgili örneklerden alıntılar yapılmıştır.

\section{Bulgular \\ Araştırmanın Kişisel Stratejiler ve Deneyimler Bölümüyle ilgili Bulgular}

Çalışmanın kişisel stratejiler ve deneyimler bölümünde ilk soruda aileleri çocuklarının eğitimlerine etkin ve bilinçli bir şekilde katılımlarını sağlamak için öğretmenlerin uyguladıkları stratejiler konusunda görüşleri elde edilmeye çalışılmıştır. Elde edilen bulgulara Tablo 1 yer verilmiştir.

Tablo 1.

Öğretmenlerin Ailelerin Çocuklarının Eğitimlerine Etkin ve Bilinçli Bir Şekilde Katılımlarını Sağlamak için Uyguladıkları Stratejiler

Görüşler $\quad f$




\begin{tabular}{lc}
\hline İşbirliği & 6 \\
İstek uyandırma & 8 \\
Birebir görüşmeler & 16 \\
Veli toplantıları & 20 \\
Okul ve ev arası bilgi alışverişi & 2 \\
Ev ziyaretleri & 5 \\
Arkadaşlık ilişkileri & 2 \\
Sosyal Etkinlik & 1 \\
Sürekli iletişim halinde olmak & 7 \\
Strateji yok & 1 \\
Önemli olan öğretmen & 2 \\
Aileleri tanımak & 1 \\
Notla iletişim & 3 \\
Kitap okuma çizelge takibi & 3 \\
Evde okuma yarışı & 1 \\
\hline
\end{tabular}

Tablo 1 incelendiğinde en çok uygulanan stratejiler olarak veli toplantıları, birebir görüşmeler ve istek uyandırma görülmektedir. Tüm bu stratejileri ise ortak payda olan iletişim altında birleştirmişlerdir. Aşağıda bu soruya ilişkin öğretmen görüşlerinden örnek alıntılara yer verilmiştir.

"Veli toplantıları ile sürekli iletişim halinde olmaya çalısılyorum. Telefon aramaları, mesaj gönderme gibi iletişimi destekleyen şeyler kullanılıyorum. (KÖ32)"

"Aileler ile birlikte sürekli işbirliği yaparak, öğrenciye gerekli desteğin verilmesi amaçlanır. Öğrencinin okuma isteği uyandırılır. (KÖ7)"

"Devamlı ailelerle içli dışı olmaya ve onları okula çocuklarının geleceğini hazırlamak için davet etme ile ilgili stratejiler uyguladım. Her bir velimi detaylı tanıyarak onlarla yakın ilişki de olmayı amaçladım. Köyde kalıyor olmamın da avantajını kullanarak bu konuda çalışmalar yaptım. (KÖ17)"

Çalışmanın kişisel stratejiler ve deneyimler bölümünün ikinci sorusunda ise öğretmenlerin uygulanan stratejilerin başarılı olup olmadığı konusundaki düşünceleri elde edilmek istenmiştir. Elde edilen bulgulara Tablo 2'de yer verilmiştir.

Tablo 2.

Öğretmenlerin Uygulanan Stratejilerin Başarılı Olup Olmadığı Konusundaki Düşünceleri

\begin{tabular}{lc}
\hline Görüşler & $f$ \\
\hline Kısmen başarııı & 11 \\
Başarılı & 18 \\
Başarılı olmadı & 6 \\
Uygulamıyorum & 3 \\
\hline
\end{tabular}

Tablo 2 incelendiğinde uygulanan stratejilerin çoğunun başarılı olduğu ancak birçoğunun da kısmen başarılı olduğu görülmektedir. Aşağıda bu soruya ilişkin öğretmen görüşlerinden örnek alıntılardan birine yer verilmiştir.

"Eğitimde ailenin desteği olduğu süreçlerde başarı çabuk elde edilir. (KÖ2)"

Çalışmanın kişisel stratejiler ve deneyimler bölümünün üçüncü sorusunda ise aile katılımının nasıl bir süreç olduğu hakkındaki öğretmen düşünceleri ele alınmıştır. Elde edilen bulgular Tablo 3'te yer verilmiştir.

Tablo 3.

Öğretmenlerin Aile Katııımının Nasıl Bir Süreç Olduğu Hakkındaki Düşünceleri

\begin{tabular}{ll}
\hline Görüşler & $f$ \\
\hline Temel aile & 5 \\
Sürekli & 9 \\
\hline
\end{tabular}




\begin{tabular}{lc}
\hline Öğrenci-öğretmen-aile üçgeni & 5 \\
Iletişim & 6 \\
Takip & 2 \\
Değer vermek & 1 \\
Gerekli & 1 \\
Ailenin görevi & 5 \\
Eğitim devamı & 3 \\
Yol gösterici & 3 \\
Desteklemek & 4 \\
Olumlu-olumsuz & 3 \\
Önemli süreç & 7 \\
Farklı zorluklar & 5 \\
Bölgesel açıdan & 5 \\
Başarı anahtarı & 1 \\
\hline
\end{tabular}

Tablo 3 incelendiğinde aile katılımının sürekli, önemli bir süreç olduğu ve iletişim ile sağlanabileceğini dair bulgulara ulaşılmıştır. Aşağıda bu soruya ilişkin öğretmen görüşlerinden örnek alıntılara yer verilmiştir.

"Sürekliliği olan ve olması gereken bir süreç. (KÖ28)"

"Bulunduğu yere göre farklı zorlukları olan ve her daim üzerinde kafa yorulması ve ekstra çalışma gerektiğini düşünüyorum. (KÖ17)”

"Aile katılımı; ailenin öğrencinin dersleriyle alakadar olması ve çocuğu hakkında öğretmenle sürekli bir iletişim içinde olmasıdır. (KÖ37)"

Çalışmanın kişisel stratejiler ve deneyimler bölümünün dördüncü sorusunda ise katılımcıların çalıştıkları okulda ailelerin etkin katılım düzeyleri noktasındaki görüşleri elde edilmek istenmiştir. Elde edilen bulgulara Tablo 4'te yer verilmiştir.

Tablo 4.

Çalıștıkları Okulda Ailelerin Etkin Katılım Düzeylerine ilişskin Öğretmen Görüşleri

\begin{tabular}{lc}
\hline Görüşler & $f$ \\
\hline Her sene azalıyor & 2 \\
Katılım yetersiz & 19 \\
Etkin katııım var & 10 \\
Okul-aile işbirliğinde çoğunluk & 2 \\
Katılım yok & 6 \\
Veliye bağlı & 1 \\
Orta düzeyde & 3 \\
Katılım bilinçli değil & 1 \\
\hline
\end{tabular}

Tablo 4 incelendiğinde ailelerin etkin katılımın yetersiz olduğu görülmektedir. Aşağıda bu soruya ilişkin öğretmen görüşlerinden örnek alıntılardan birine yer verilmiştir.

"Maalesef istenilen düzeyde katılım söz konusu değil, ailelerin eğitim algısı, yaşam şekilleri ve ekonomik uğraşları bu durumun en büyük sebeplerindendir. (KÖ24)"

Çalışmanın kişisel stratejiler ve deneyimler bölümünün beşinci sorusunda ise şuan okuttukları sınıftaki öğrenci ailelerinin etkin katılımı ile ilgili düşünceleri elde edilmek istenmiştir. Elde edilen bulgulara Tablo 5'te yer verilmiştir.

Tablo 5.

Öğretmenlerin Şuan Okuttukları Sınıftaki Öğrenci Ailelerinin Etkin Katılımı ile ilgili Düşünceleri

\begin{tabular}{lc}
\hline Görüşler & $f$ \\
\hline Hepsi ile etkin katılım & 12 \\
\hline
\end{tabular}




\begin{tabular}{lc}
\hline Veliler arasında rekabet & 1 \\
Sınıfın yarısında katıım & 7 \\
Etkin katııım başarıyı arttırır & 1 \\
Katııım yok & 5 \\
Düşük katıım & 12 \\
Çoğunlukta katııım & 3 \\
Öğretmenin çabasıyla & 2 \\
Bilinçli ailelerde katıım & 2 \\
\hline
\end{tabular}

Tablo 5 incelendiğinde en çok iki görüşün ortaya çıktığı görülmüştür. Bu görüşlerden biri hepsi ile etkin katıım bir diğeri ise düşük katılımdır. Aşağıda bu soruya ilişkin öğretmen görüşlerinden örnek alıntılara yer verilmiştir.

"Çok fazla etkin katılım olduğunu söylemek imkânsızdır. (KÖ21)"

"Veliler rekabet halinde ve daha duyarlılar. (KÖ6)"

Çalışmanın kişisel stratejiler ve deneyimler bölümünün altıncı sorusunda ise sınıfta okuma ve yazma açısından çok fazla aile desteği gören öğrencilerin durumu sorgulanmıştır. Elde edilen bulgulara Tablo 6'da yer verilmiştir.

Tablo 6.

Sınıfta Okuma ve Yazma Açısından Çok Fazla Aile Desteği Gören Öğrencilerin Durumuna iliş̧kin Ögrretmen Görüşleri

\begin{tabular}{lc}
\hline Görüşler & $f$ \\
\hline Var & 19 \\
Yok & 12 \\
$1 / 3$ oranında & 1 \\
Birkaç öğrenci & 10 \\
$\% 50$ oranında & 1 \\
\hline
\end{tabular}

Tablo 6 incelendiğinde sınıfta okuma ve yazma desteği alan öğrencilerin var olma durumunun yüksek olduğu görülmektedir. Aşağıda bu soruya ilişkin öğretmen görüşlerinden örnek alıntılardan birine yer verilmiştir.

"Hayır. Sadece özel gereksinimli öğrencim çok fazla aile desteği alıyor. (KÖ26)"

Çalışmanın kişisel stratejiler ve deneyimler bölümünün yedinci sorusunda ise aile desteği gören öğrencilerin durumları hakkındaki görüşleri elde edilmek istenmiştir. Elde edilen bulgular Tablo 7'de verilmiştir.

Tablo 7.

Aile Desteği Gören Öğrencilerin Durumları Hakkındaki Öğretmen Görüşleri

\begin{tabular}{lc}
\hline Görüşler & $f$ \\
\hline Ekonomik durum & 14 \\
Sosyal çevre & 15 \\
Özgüven yüksek & 7 \\
Okula, derslere daha ilgili & 1 \\
Üretken & 1 \\
Çözüm odaklı & 1 \\
Başarı & 14 \\
Aileler eğitime önem & 2 \\
Kesinlik yok & 5 \\
Fark var & 3 \\
Özel gereksinimli & 1 \\
Arkadaş ilişkileri & 1 \\
\hline
\end{tabular}


Tablo 7 incelendiğinde aile desteği gören öğrencilerin durumları hakkındaki görüşlerinden sosyal çevre, ekonomik durum ve akademik başarı olarak farklılıklarının olduğu görülmektedir. Aşağıda bu soruya ilişkin öğretmen görüşlerinden örnek alıntılara yer verilmiştir.

"Sınıfın başarı düzeyi açısından önden gelen öğrencilerini, ailelerini desteğini gören öğrenciler oluşturmaktadır. (KÖ42)"

Çalışmanın kişisel stratejiler ve deneyimler bölümünün diğer sorusunda ailelerinin katılımıyla çocukların okuma ve yazma başarılarında önemli gelişmelerin olup olmadığı hakkındaki görüşler elde edilmek istenmiştir. Elde edilen bulgular Tablo 8'de verilmiştir.

Tablo 8.

Ailelerinin Katılımıyla Çocukların Okuma ve Yazma Başarısındaki Gelişmeler Hakkındaki Öğretmen Görüşleri

\begin{tabular}{lr}
\hline Görüşler & $f$ \\
\hline Oldu & 40 \\
Okuma Yazma & 1 \\
Dikte & 1 \\
Olmadı & 3 \\
Beceriyi kalıcılaştırma & 1 \\
Ödevleri yapmak & 1 \\
\hline
\end{tabular}

Tablo 8 incelendiğinde öğretmenlerin ailelerinin katılımıyla çocukların okuma ve yazma başarısında önemli gelişmelerin olduğu yönünde görüşlerini bildirmişlerdir. Aşağıda bu soruya ilişkin öğretmen görüşlerinden örnek alıntılara yer verilmiştir.

"Evet oldu. Özellikle eğitim derecesi yüksek ailelerde. (KÖ1)"

"Tabi ki de oldu. Öğrencinin özellikle öğretimi pekiştirme aşamasında aile desteğinin katkısı öğrencide beceriyi kalıcılaştırmada oldukça etkili olduğunu söyleyebilirim. (KÖ24)"

Çalışmanın kişisel stratejiler ve deneyimler bölümünün diğer sorusunda aileleri etkin olarak katılmayan çocukların sınıftaki başarıları hakkında öğretmen görüşleri belirlenmek istenmiştir. Elde edilen bulgular Tablo 9' da verilmiştir.

Tablo 9.

Aileleri Etkin Olarak Katılmayan Çocukların Sınıftaki Başarıları Hakkındaki Öğretmen Görüşleri

\begin{tabular}{lc}
\hline Görüşler & $f$ \\
\hline Var & 29 \\
Kısmen var & 5 \\
Yok & 8 \\
Hemen hemen hepsi & 1 \\
Dezavantaj & 1 \\
Başarısız & 3 \\
Farklı yollarla gidermek & 1 \\
Ailenin önem vermemesi & 1 \\
Çocuklardaki istek & 1 \\
Sosyal anlamda da farklılık & 1 \\
\hline
\end{tabular}

Tablo 9 incelendiğinde aileleri etkin olarak katılmayan çocukların sınıf içerisindeki varlığının fazla olduğu belirlenmiştir. Aşağıda bu soruya ilişkin öğretmen görüşlerinden örnek alıntılara yer verilmiştir.

"Söylediğim gibi zaten çoğunluğunu bu tarz velilerin oluşturduğu öğrencilerim var. Bu da hem akademik başarıyı düşürüyor hem de sosyal anlamda da diğer öğrencilerden farklılık gösteriyor. (KÖ17)" 
"Aileleri etkin katılmayan öğrencilere göre aileleri etkin katılım gösteren öğrenciler daha istekli olanlar gayet başarılıdır. (KÖ23)"

Çalışmanın kişisel stratejiler ve deneyimler bölümünün diğer bir sorusunda aileleri etkin olarak katılmayan çocukların durumları ile ilgili öğretmen görüşleri elde edilmek istenmiştir. Elde edilen bulgular Tablo 10 'da verilmiştir.

Tablo 10.

Aileleri Etkin Olarak Katılmayan Çocukların Durumları ile ilgili Öğretmen Görüşleri

\begin{tabular}{lc}
\hline Görüşler & $f$ \\
\hline Yetersiz sosyal ilişki ve çevre & 13 \\
Zayıf ekonomik durum & 9 \\
Cevap yok & 6 \\
Sorunlu öğrenciler & 2 \\
Düşük akademik başarı & 5 \\
Ekonomik duruma verilen önem & 3 \\
Öğrencinin kendi çabası & 1 \\
Ailenin önceliği & 13 \\
Ekonomik durum etkili değil & 3 \\
Özgüven & 2 \\
\hline
\end{tabular}

Tablo 10 incelendiğinde aileleri etkin olarak katılmayan çocukların durumları ile ilgili yetersiz sosyal ilişki ve çevre ve ailenin önceliği ön plana çıkmıştır. Aşağıda bu soruya ilişkin öğretmen görüşlerinden örnek alıntılara yer verilmiştir.

"Ailenin ekonomik durumu-uğraşları, çocuklara gereken özeni göstermede bir engel oluşturmaktadır. Köyle sınırı kalan sosyal çevre yüzünden çocuklar kendini geliştirememektedir. (KÖ24)"

"Ekonomik durumları iyi değil. Annesi okuma yazma bilmeyen var. Babaları sürekli şehir dışında ya da tüm gün (hafta sonu dâhil) işteler. (KÖ27)

Araştırmanın kişisel stratejiler ve deneyimler bölümünün diğer bir sorusunda okuma ve yazma sürecine etkin katılan ailelerin değerlendirmelerde çocuklarının üzerinde baskılar oluşturup oluşturmadığı konusundaki öğretmen görüşleri elde edilmek istenmiştir. Elde edilen bulgular Tablo $11^{\prime}$ de verilmiştir.

Tablo 11.

Okuma ve Yazma Sürecine Etkin Katılan Ailelerin Bu Değerlendirmelerde Çocuklarının Üzerinde Baskılar Oluşturup Oluşturmadıkları Konusundaki Öğretmen Görüşleri

\begin{tabular}{lc}
\hline Görüşler & $f$ \\
\hline Baskı oluşturmuyor & 18 \\
Bazen baskı oluşturabiliyor & 16 \\
Yönlendirme & 3 \\
Baskı oluşturuyor & 6 \\
Önlem & 2 \\
Çocuklara göre aile katılımı & 1 \\
Yanlış yöntem & 1 \\
Olumlu yönde baskı & 1 \\
\hline
\end{tabular}

Tablo 11 incelendiğinde okuma ve yazma sürecine etkin katılan ailelerin bu değerlendirmelerde çocuklarının üzerinde baskılar oluşturup oluşturmadıkları hakkında baskı oluşturmuyor ve bazen baskı oluşturabildikleri görüşleri oldukça yüksek çıkmıştır. Aşağıda bu soruya ilişkin öğretmen görüşlerinden örnek alıntılara yer verilmiştir.

"Baskı oluşturan velim olmadı. Sonuçları haberdar ettiğim için önlemler aldık ve çocukların ilerlemesini sağladık. Sorunlar çabuk çözüldü. (KÖ38)" 
Öğretmenlerin Gözünden İlkokul Birinci Sınıf Öğrencilerin Okuma Yazma Becerilerini Öğrenme Süreçlerine Ailelerin Katılımı

"Az da olsa baskı oluşturuyor. Ama bu baskı gelecek günlerde öğrenciyi pozitif yönde etkiliyor. (KÖ33)"

\section{Araştırmanın Inançlar Bölümündeki Sorulara iliş̧in Bulgular}

Araştırmanın inançlar bölümündeki ilk sorusunda uygun aile katılımı hakkındaki katılımcıların görüşleri elde edilmek istenmiştir. Elde edilen bulgular Tablo 12'de verilmiştir.

Tablo 12.

Uygun Aile Katılımı Hakkındaki Katılımcıların Görüşleri

\begin{tabular}{lc}
\hline Görüşler & $f$ \\
\hline İlgi & 12 \\
Iletişim & 11 \\
Baskı boyutunda olmamalı & 1 \\
Destek & 11 \\
İşbirliği & 5 \\
Fayda & 2 \\
Rehber aile & 5 \\
Sürekli & 3 \\
Öğretim okulda yapılmalı & 3 \\
Akademik başarı artar & 1 \\
Öğretmen okulda aile dışarıda & 1 \\
Çocuğun seviyesine inmek & 2 \\
\hline
\end{tabular}

Tablo 12 incelendiğinde ise uygun aile katılımı hakkında elde edilen görüşler ilgi, iletişim ve destek olunması yönünde ortaya çıkmıştır. Aşağıda bu soruya ilişkin öğretmen görüşlerinden örnek alıntılara yer verilmiştir.

"Çocuğunu çok fazla yargılamadan, destek alan, yol gösteren aile tipi. (KÖ16)"

"Aile katılımı sağlanmalı fakat öğretmen-aile rolleri karıştırılmamalı. (KÖ2)"

Araştırmanın inançlar bölümündeki ikinci sorusunda ailelerin çocuklarına katkı sağlamayı isteyip istemedikleri konusundaki öğretmen görüşleri elde edilmek istenmiştir. Elde edilen bulgular Tablo 13'te verilmiştir.

Tablo 13.

Ailelerin Çocuklarına Katkı Sağlamayı İsteyip istemedikleri Konusundaki Öğretmen Görüşleri

\begin{tabular}{lc}
\hline Görüşler & $f$ \\
\hline İstek var & 27 \\
Katkı yok & 3 \\
Bilinçli değil & 5 \\
Engelleyen etmenler & 1 \\
Önem vermek & 5 \\
İstemiyorlar & 18 \\
Başarılı & 1 \\
Başarısız & 2 \\
\hline
\end{tabular}

Tablo 13 incelendiğinde ailelerin çocuklarına katkı sağlamayı isteyip istemedikleri konusunda istekli olma ve olmama durumu en çok göze çarpan görüşlerden biri olmuştur. Aşağıda bu soruya ilişkin öğretmen görüşlerinden örnek alıntılara yer verilmiştir.

"Her aile çocuğuna katkı sağlamak ister. Kimi bunu başarı, kimisi başaramaz. (KÖ43)"

"Sınıfı ve uygulanan programı izlemesi, şarkı, oyun ve hikâye okuma gibi etkinliklerde öğretmenin rolünü üstlenmesi gerektiğini düşünüyorum. (KÖ1)" 
Araştırmanın inançlar bölümündeki diğer bir sorusunda katılımcıların çalıştıkları okulun aile katılımını arttırmak için çabaları hakkında görüşleri elde edilmek istenmiştir. Elde edilen bulgular Tablo 14 'te verilmiştir.

Tablo 14.

Katılımcıların Çalıştıkları Okulun Aile Katılımını Arttırmak için Çabaları Hakkındaki Görüşler

\begin{tabular}{lc}
\hline Görüşler & $f$ \\
\hline Evet & 27 \\
Illetişim & 1 \\
Rehberlik & 1 \\
Bilgilendirme çalışmaları & 1 \\
Orta seviyede & 6 \\
Düşünmüyorum & 9 \\
\hline
\end{tabular}

Tablo 14 incelendiğinde katılımcıların çalıştıkları okulun aile katılımını arttırmak için çabaladıkları ortaya çıkmıştır. Aşağıda bu soruya ilişkin öğretmen görüşlerinden örnek alıntılara yer verilmiştir.

"Küçük bir okulda yapılması gerekeni yapıyorlar. (KÖ19)"

"Düşünüyorum. Okulumuzun öğretmenleri velilerimize sürekli rehberlik ediyorlar. Bilgilendirme çalışmaları yapıyorlar. (КÖ38)"

"Okulumuz gerek idare gerek öğretmenler olarak ailelerle sürekli irtibat halinde ve aileleri bilgilendirmektedir. (KÖ40)"

Araştırmanın inançlar bölümündeki diğer bir sorusunda hangi tür aile katılımının çocuğun okuma ve yazma başarısında daha etkili olduğu konusunda öğretmen görüşleri elde edilmek istenmiştir. Elde edilen bulgular Tablo 15'te verilmiştir.

Tablo 15.

Hangi Tür Aile Katılımının Çocuğun Okuma ve Yazma Başarısında Daha Etkili Olduğu Hakkındaki Öğretmen Görüşleri

\begin{tabular}{lc}
\multicolumn{1}{c}{ Görüşler } & $f$ \\
\hline Sürekli iletişim halinde & 4 \\
Düzenli katılım & 1 \\
Maddi olmayan & 1 \\
Sevgi ve ilgi & 11 \\
İşbirliği & 10 \\
Bireysel görüşmeler & 1 \\
Destek & 11 \\
Yol gösterici & 1 \\
İyi örnek & 1 \\
Sürekli & 1 \\
Bilinçli & 1 \\
Yeterli ölçüde & 2 \\
\hline
\end{tabular}

Tablo 15 incelendiğinde sevgi ve ilgiye dayalı, öğrenciye destek verilen ve iş birliği içerisinde olunan aile katılımının çocuğun okuma ve yazma başarısında daha etkili olduğu görüşleri ortaya çıkmıştır. Aşağıda bu soruya ilişkin öğretmen görüşlerinden örnek alıntılara yer verilmiştir. "Öğretmene saygı unsurunu göz önünde bulunduran, çocukları ile vakit geçiren. (KÖ22)" "Öğretmenle sürekli görüş alış-verişinde olan bir aile çocuğunun nerede eksik kaldığını nerede yardıma ihtiyaç duyacağını iyi bilir. Bu da doğru müdahale demektir. (KÖ36)" 
Öğretmenlerin Gözünden İlkokul Birinci Sınıf Öğrencilerin Okuma Yazma Becerilerini Öğrenme Süreçlerine Ailelerin Katılımı

Araştırmanın inançlar bölümündeki diğer bir sorusunda ailelerin katılımında çocuklar için faydasız olan bir durum görüp görmedikleri hakkındaki öğretmen görüşleri elde edilmek istenmiştir. Elde edilen bulgular Tablo 16'da verilmiştir.

Tablo 16.

Ailelerin Katıımında Çocuklar için Faydasız Olan Bir Durum Görüp Görmedikleri Hakkındaki Görüşleri

\begin{tabular}{lc}
\hline Görüşler & $f$ \\
\hline Hayır & 21 \\
Baskı & 4 \\
İstek dışında & 3 \\
Şiddet ve tehdit & 1 \\
İşbirliği & 1 \\
Evet & 14 \\
Yanlış öğretimler & 7 \\
Karşılaştırma yapılması & 2 \\
Bilinçsiz destek & 3 \\
\hline
\end{tabular}

Tablo 16 incelendiğinde ailelerin katılımında çocuklar için faydasız bir durum olmadığı ve olduğu durumları ortaya çıkmıştır. Aşağıda bu soruya ilişkin öğretmen görüşlerinden örnek alıntılardan birine yer verilmiştir.

"Görüyorum. Aşırı baskı olunca çocuklar isteksizleşiyor. (KÖ34)"

"Tamamen faydasız. Çünkü okuma-yazma faaliyetlerini nasıl yapılması gerektiğini bilmiyorlar. (KÖ23)"

Araştırmanın inançlar bölümündeki diğer bir soruda öğretmenlerin sınıflarında aile katııımına yönelik etkili stratejiler uygulayıp uygulamadıkları hakkındaki görüşleri elde edilmek istenmiştir. Elde edilen bulgular Tablo 17' de verilmiştir.

Tablo 17.

Öğretmenlerin Sınıflarında Aile Katılımına Yönelik Etkili Stratejiler Uygulayıp Uygulamadıkları Hakkındaki Görüşler

\begin{tabular}{lc}
\hline Görüşler & $f$ \\
\hline Evet & 28 \\
Ailelere ulaşıp ulaşmama & 1 \\
Her zaman için daha iyisi & 2 \\
Bazen & 2 \\
Yönlendirici notlar & 1 \\
Uygulamıyorum & 1 \\
Ailelerden de ilgi & 1 \\
Hayır & 6 \\
Şartlar & 2 \\
\hline
\end{tabular}

Tablo 17 incelendiğinde genel olarak öğretmenler sınıf içerisinde aile katılımına yönelik etkili stratejiler uyguladıkları konusunda görüşlerini dile getirmişlerdir. Aşağıda bu soruya ilişkin öğretmen görüşlerinden örnek alıntılara yer verilmiştir.

"Etkili stratejiler uygulansa da uygun ortam ve şartlardan dolayı maalesef etkililik yönünden zayıf kalmakta. (KÖ24)"

"Bazı teknikler ailelere anlatılıyor, ama bazıları için bu söylenemez. (KÖ6)"

"Gerekli gördügüm süreçlerde aile katıııını sağlayarak, bireysel görüşmeler yaparak. (KÖ2)"

Araştırmanın inançlar bölümündeki diğer bir soruda hangi problemlerin ailelerin etkin katılımına engel olduğu hakkındaki öğretmen görüşleri elde edilmek istenmiştir. Elde edilen bulgular Tablo $18^{\prime}$ de verilmiştir. 
Tablo 18.

Hangi Problemlerin Ailelerin Etkin Katılımına Engel Olduğu Hakkındaki Öğretmen Görüşleri

\begin{tabular}{lc}
\hline Görüşler & $f$ \\
\hline Okuma yazma problemi & 3 \\
Eğitim düzeyleri & 15 \\
Ekonomik durum & 16 \\
İstikrarsızlık & 1 \\
Sosyal çevre & 8 \\
Ön yargılar & 2 \\
Kalıplaşmış inançlar & 1 \\
Öğretmen ile iletişim & 1 \\
Eğitime verilen önem & 10 \\
Yaşam koşulları & 8 \\
\hline
\end{tabular}

Tablo 18 incelendiğinde ekonomik durum, eğitim düzeyleri ve eğitime verilen önem gibi problemlerin ailelerin etkin katılımına engel olduğu görüşleri ortaya çıkmıştır. Aşağıda bu soruya ilişkin öğretmen görüşlerinden örnek alıntılara yer verilmiştir.

"Eğitimin sadece okulda olduğu düşüncesi çocuğuyla ilgisiz ve sorumluluk almak istemeyen aileler. (KÖ18)"

"Ailedeki iş yükünün çokluğu ve ailelerin bu konudaki bilgisizliği. (KÖ38)"

"Maddi sıkıntılar, geçim tarzı, yöresel nedenler vb.(KÖ40)"

Araştırmanın inançlar bölümündeki diğer bir soruda okuma ve yazma başarısı ile aile katııımı arasında olumlu ilişkilerin olup olmadığı hakkındaki öğretmen görüşleri elde edilmek istenmiştir. Elde edilen bulgular Tablo 19'da verilmiştir.

Tablo 19.

Okuma ve Yazma Başarısı ile Aile Katılımı Arasında Olumlu ilişsilerin Olup Olmadığı Hakkındaki Görüşler

\begin{tabular}{lc}
\hline Görüşler & $f$ \\
\hline Evet & 39 \\
Önemli ve gerekli & 1 \\
Doğru orantı & 3 \\
Hayır & 1 \\
\hline
\end{tabular}

Tablo 19 incelendiğinde okuma ve yazma başarısı ile aile katılımı arasında olumlu ilişkilerin olduğu düşüncesi ortaya çıkmıştır. Aşağıda bu soruya ilişkin öğretmen görüşlerinden örnek alıntılara yer verilmiştir.

"Yeterli aile katılımının öğrenci başarısına olumlu katkısı olduğunu düşünüyorum. (KÖ8)"

"Okuma-yazma ile aile katılımı en önemli ve gerekli olan ilişkidir. (KÖ40)"

"Kesinlikle birbiriyle yakından ilişkili olduğunu düşünüyorum. Böyle olduğunu da çocukların olumlu davranışları ortaya koyuyor. (KÖ17)"

Araştırmanın inançlar bölümündeki onuncu soruda ise ailelerin çocuklarının okuma ve yazma eğitim süreçlerine katılımında kendilerini rahat hissetmeleri konusundaki öğretmen görüşleri elde edilmek istenmiştir. Elde edilen bulgular Tablo 20'de verilmiştir.

Tablo 20.

Ailelerin Çocuklarının Okuma ve Yazma Eğitim Süreçlerine Katılımında Kendilerini Rahat Hissetmeleri Konusundaki Öğretmen Görüşleri

\begin{tabular}{lc}
\hline Görüşler & $f$ \\
\hline Evet & 22 \\
Doğru teknikler & 1 \\
Stres & 2 \\
\hline
\end{tabular}


Öğretmenlerin Gözünden İlkokul Birinci Sınıf Öğrencilerin Okuma Yazma Becerilerini Öğrenme Süreçlerine Ailelerin Katılımı

\begin{tabular}{lc}
\hline Geri planda & 1 \\
Bazı zamanlarda & 1 \\
İstekli & 2 \\
Hayır & 16 \\
Şikâyet & 1 \\
Öncelik & 1 \\
Gerekli bilgilendirme & 1 \\
Önyargı & 1 \\
Bilinçli aile & 2 \\
\hline
\end{tabular}

Tablo 20 incelendiğinde ailelerin çocuklarının okuma ve yazma eğitim süreçlerine katılımında kendilerini rahat hissettikleri ve aynı zamanda hissetmedikleri konusunda görüşler ortaya çıkmıştır. Aşă̆ıda bu soruya ilişkin öğretmen görüşlerinden örnek alıntılara yer verilmiştir.

"Istekli olan ailelerin kendilerini rahat hissettiklerini düşünüyorum. (KÖ9)"

"Çok fazla değiller. Çünkü bu iş aileler içinde sıkıntı oluşturuyor. (KÖ21)"

"Daha öncelikli işlerinin olduğunu düşünüyorum ve bu konuda pek de rahat olduklarını söyleyemem. Çok az velimde bu rahatlık olabilir. (KÖ17)"

Araştırmanın inançlar bölümündeki diğer bir soruda ailelerin çocuklarının okuma ve yazma eğitimlerine katılma süreçlerinde size veya diğer okul personeline ulaşmada kendilerini rahat hissetmeleri konusundaki öğretmen görüşleri elde edilmek istenmiştir. Elde edilen bulgular Tablo $21^{\prime}$ de verilmiştir.

Tablo 21.

Ailelerin Çocuklarının Okuma ve Yazma Eğitimlerine Katılma Süreçlerinde Öğretmene veya Diğer Okul Personeline Ulaşmada Kendilerini Rahat Hissetmeleri Konusundaki Öğretmen Görüşleri

\begin{tabular}{lc}
\hline Görüşler & $f$ \\
\hline Evet & 39 \\
İletişim & 4 \\
İsteme durumu & 1 \\
Rahatsı hissetme & 3 \\
Ulaşım & 1 \\
\hline
\end{tabular}

Tablo 21 incelendiğinde ailelerin çocuklarının okuma ve yazma eğitimlerine katılma süreçlerinde tüm okul personellerine rahat bir şekilde ulaşabilecekleri dile getirilmiştir. Aşağıda bu soruya ilişkin öğretmen görüşlerinden örnek alıntılara yer verilmiştir

"Evet istediklerinde rahat ulaşabilme imkanları vardır. Iletişim kurarlarken de rahat hissettirmeye çalısıllmaktadır. (KÖ12)"

"Evet bu konuda oldukça rahatlar. Okul köyün içinde ve yakın olduğu içinde kolayca ulaşabiliyorlar ve rahat olduklarından da eminim. (KÖ17)"

"Evet. Telefon ve yüz yüze görüşmemizde kısıtlamamız yok. (КÖ38)"

Araştırmanın inançlar bölümündeki diğer bir soruda ailelerin çocuklarının okuma ve yazma eğitim süreçlerine etkin katılma konusunda sorumluluk sahibi olup olmadıkları hakkındaki öğretmen görüşleri öğrenilmek istenmiştir. Elde edilen bulgular Tablo 22' de verilmiştir.

Tablo 22.

Ailelerin Çocuklarının Okuma ve Yazma Eğitim Süreçlerine Etkin Katılma Konusunda Sorumluluk Sahibi Olup Olmadıkları Hakkındaki Öğretmen Görüşleri

\begin{tabular}{ll}
\hline Görüşler & $f$ \\
\hline Evet & 13 \\
Nadiren & 11 \\
Hayır & 13 \\
\hline
\end{tabular}




\begin{tabular}{lc}
\hline Çoğunluk & 4 \\
İlgi & 1 \\
Ailelere göre & 1 \\
\hline
\end{tabular}

Tablo 22 incelendiğinde ailelerin çocuklarının okuma ve yazma eğitim süreçlerine katılıma konusunda sorumluluk sahibi oldukları ve olmadıkları iki durumda ortaya çıkmıştır. Aşağıda bu soruya ilişkin öğretmen görüşlerinden örnek alıntılara yer verilmiştir.

"Ailelerin bir kısmı sorumluluk sahibi bir kısmı değil. (KÖ20)"

"Büyük çoğunluğu için evet, bazı aileler ise bu durumu çok fazla umursamıyor. (KÖ16)"

"En büyük sorumluluğun aileye ait olduğunu düşünüyorum. Ailenin yükleneceği ve uygulayacağı sorumlulukların yerine getirmede oldukça önemli misyona sahiptir. (KÖ24)"

Araştırmanın inançlar bölümündeki diğer bir soruda ise bazı ailelerin çocuklarının bu süreçlerine katılmada herhangi bir sorumluluklarının olmadığını, bu sürecin sadece öğretmenin sorumluluğunda olması gerektiğini konusundaki öğretmen görüşleri elde edilmek istenmiştir. Elde edilen bulgular Tablo 23 'te verilmiştir.

Tablo 23

Bazı Ailelerin Çocuklarının Bu Süreçlerine Katılma da Herhangi Bir Sorumluluklarının Olmadığını, Bu Sürecin Sadece Öğretmenin Sorumluluğunda Olması Gerektiği Konusundaki Öğretmen Görüşleri

\begin{tabular}{lc}
\hline Görüşler & $f$ \\
\hline Evet & 29 \\
Hayır & 10 \\
Bazıları için & 3 \\
Aile sorunları & 1 \\
Tek sorumluluk öğretmenin algısı & 5 \\
Aile desteğinin önemi & 1 \\
Veli ziyaretleri & 1 \\
Sorumluluk ortak & 2 \\
Kısmen & 1 \\
\hline
\end{tabular}

Tablo 23 incelendiğinde ise bazı ailelerde tüm sorumluluğun öğretmende olması gerektiği yönünde bir düşüncenin hâkim olduğu görülmüştür. Aşağıda bu soruya ilişkin öğretmen görüşlerinden örnek alıntılara yer verilmiştir.

"Çocukların sadece okuldaki eğitimle de okuma ve yazmayı öğrenebilecekleri düşüncesiyle aile katılımının çok gerekli olmadığını düşünmektedirler. (KÖ23)"

"Birçok ailede böyle bir düşünce vardır. Çocuğun başarı durumunun sadece öğretmeni ilgilendirdiği eğer çocuk başarısızsa bunun tek sorulusunun öğretmen olduğu söylenmektir. (KÖ40)”

"Evet düşünüyorum. 'Akşam ödevleri ben yaptıracaksam öğretmen ne iş yapıyor? (KÖ16)"

\section{Tartışma ve Sonuç}

Araştırmanın kişisel stratejiler ve deneyimler bölümüyle ilgili öğretmen görüşleri genel olarak değerlendirildiğinde ailelerin çocukların eğitim sürecine etkin ve bilinçli bir şekilde katılım göstermeleri için öğretmenlerin uyguladıkları stratejiler öğrenilmek istenilmiştir. En çok uygulanan strateji olarak veli toplantıları ve birebir görüşmeler düzenledikleri göze çarpmaktadır. Bu stratejilerin yanında işbirliği içerisinde olmak, devamlı iletişimi sağlamak ve ailede de isteği uyandırmak adına çalışmaların yapıldığı gözler önüne serilmiştir. Günümüzde çağdaş eğitim anlayışında ev ile okul yaşantısı zincirlerini oluşturmak ve eğitimde devamlılı̆̆ sağlamak başarılı bir okul aile işbirliği ile gerçekleşmektedir (Çağdaş ve Seçer, 2011). Etkili bir aile öğretmen iletişimi çocukların öğrenmelerine destek olur ve okul aile işbirliğinin büyüyerek gelişmesine yardım eder (Atabey ve Tezel-Şahin, 2011). Aile ve öğretmenler arasında iletişimi devam ettirmek ve geliştirmek için farklı teknikler kullanılmaktadır. Telefon görüşmeleri, kitapçıklar, teyp ve video kayıtları, fotoğraflar, duyuru panoları, bültenler, haber 
mektupları, yazışmalar, portfolyo dosyaları, toplantılar, okul ziyaretleri, geliş-gidiş zamanları vb. bu tekniklere örnek verilebilir (Balcı ve Tezel-Şahin, 2018). Değişen toplumsal ve sosyal yapı ile iletişimden tam anlamıyla verim alabilmek için teknolojinin ve çağın gerektirdiği alternatif iletişim yolları da kullanılmaktadır (Balcı, 2017).

Öğretmenler tarafından aile katılımını artırmak için uygulanan stratejilerin başarılı olup olmadığı ile ilgili görüşler değerlendirildiğinde bu stratejilerin bir kısmı başarılı olarak değerlendirilirken, bir kısmı ise kısmen başarılı olarak değerlendirilmiştir. Bunun sebebi olarak ailenin eğitim düzeyi, sosyo-ekonomik durumunun etkilediği düşünülmektedir. Ailelerin etkin katılımını ve işbirliğini engelleyen faktörler olarak ailenin kendi okul yaşantısı ile ilgili olumsuzluğu, ekonomik sorunları, okula ayıracak zaman sıkıntısının olması, eğitim düzeyinin düşük olması, öğretmenlerin olumsuz tutumları ve ev ve okul kültürünün farklılığı olarak gösterilebilir (Selanik-Ay ve Aydoğdu, 2016).

Aile katılımının nasıl bir süreç olduğu konusunda öğretmenlerin görüşleri değerlendirildiğinde birçok farklı görüş ortaya çıkmıştır. Aile katııımı sürecinin bir süreklilik içerisinde olması gerektiği dile getirilen görüşlerden biri olmuştur. Aynı zamanda önemli bir süreç olduğu ve devamlı iletişim halinde bulunulması gerektiğine dair görüşler ortaya çıkmıştır. Ailenin temel yapı taşı olması ve okul-aileöğretmen üçgeninin sağlamlaştırılarak bu sürecin daha sağlıklı olacağı yöndeki görüşler de durumun önemini ortaya koymuştur. Ailelerin çocuklarının toplumsallaşmasına yardım etme, değerler kazandırma, özgüvenlerinin gelişimini destekleme, girişimcilik gibi becerilere sahip olmasını sağlama, çocukları ile kaliteli zaman geçirme gibi pek çok rol ve sorumlulukları olduğu ve bunları çocuklarına kazandırdıkları ifade edilmektedir (Selanik-Ay ve Aydoğdu, 2016). Yapılan çalışmalarda ailelerin okulda geçirdikleri zaman ile çocuklarının sahip oldukları temel okul becerileri arasında anlamlı bir ilişkinin olduğu görülmüştür. Bu sebeple ailelerin çocuklarını desteklemeye yönelik tutumlarının, bakış açılarının ve etkinliklere çocuklarıyla birlikte katılımının önem taşıdığı belirtilmektedir (Ünüvar, 2010).

Öğretmenlerin okuldaki aile katılım düzeyleri ile görüşleri genel olarak değerlendirildiğinde bir grup öğretmen katılımın yetersiz olduğunu, diğer bir grup öğretmen ise katılım yeterli olduğunu bildirmiştir. Katılımın yeterli olduğu konusunda görüş bildiren öğretmenlerin aile katılımının olumsuz sonuçlarından etkilenmemek adına aile katılımından beklentilerini düşük tutmuşlardır. Aile katılımını eleştirilere açan en önemli olumsuzluklar; ebeveynlerin eğitim düzeylerinin düşük olması, birçoğunun sorumluluk alabilecek bilişsel yeterlikte olmaması ve küreselleşmenin etkisiyle aile kurumunun parçalanarak yok olmaya yüz tutması gibi sebepler gösterilmektedir (Ilgar ve Coşkun-llgar, 2018). Ailenin eğitime verdiği önem aile katılımını oldukça etkilemektedir. Bölge halkının yer yer değişik düşünceler göstermesinin en büyük sebebi olarak eğitime verdikleri önem gösterilebilir. Bu farklılık sınıf içerisinde dahi aileden aileye değişmektedir. Ailenin eğitime verdiği önem doğrultusunda eğitimde verim de artmaktadır. Öğretmen okula yönelik olumsuz deneyim ve tutumlara sahip ailelerin de var olabileceğini de göz önünde bulundurarak istekli ve kararlı uygulamalarla ailelerim eğitim sürecine katııımlarını sağlamalıdır. Aynı zamanda öğretmenlerinde bu süreçte aileler ile sağlıklı bir iletişim ve ilişkilerin kurulabilmesi için gerekli öz yeterliliğe sahip olması gerekmektedir (Çamlıbel-Çakmak, 2010).

Öğretmen görüşleri doğrultusunda sınıflarda aile desteği gören öğrencilerin var olduğu ancak sınıfın tamamını kapsamadığı gözler önüne serilmiştir. Katılımcılardan biri kaynaştırma öğrencisinin aile desteğini çok fazla gördüğünü belirtmiştir. Bu durum bazı ailelerin çocuğun durumunu, ihtiyacını fark ederek hareket ettiklerini de ortaya çıkarmaktadır. Dezavantajı çocukların hedeflenen becerilere sahip olmalarında okulda öğrencilerin edindikleri bilgi ve becerilerin farklı ortamlarda ve günlük yaşamlarında da genellemeleri oldukça önemlidir. Bu sebeple ailelerin çocuklarının eğitimlerine katılmaları gerekmektedir. Aileler çocukların okulda öğrendiklerini günlük yaşamda da kullanmalarını sağlayarak bilgi ve becerinin kalıcılı̆ını sağlamakta en önemli görevi üstlenmiş olurlar (Yıldız, 2017).

Öğretmenlerin aile desteği gören öğrencilerin durumları ile ilgili görüşleri değerlendirildiğinde aile desteği gören öğrencilerin sosyal çevre, akademik başarı ve ekonomik durum yönünden farklılıklar taşıdıkları görülmektedir. Tüm bu ortaya çıkan farklılıkların yanında özgüvenlerinin yüksek olduğu da gözler önüne serilmiştir. Bireyin özgüven geliştirebilmesi için temel değerler her zaman yol gösterici konumda olmalıdır. Birey belli temel değerler doğrultusunda hayatını anlamlandıramıyorsa özgüvenleri bu durumdan olumsuz etkilenecektir. Çocuğun aileden ve çevreden gördüğü yaşantılarını sevgi ve saygıya dayalı olması ve sosyal hayata katılmasıyla birlikte kendine olan özgüveni de gelişecektir. 
Özgüven değerinin çocukta oluşmasında ve gelişmesinde ailenin, okulun ve arkadaş çevresinin etkisi büyüktür. Bu sebeple aile ve okul yaşamında değerler eğitiminin önemsenerek etkili olarak verilmesi gerekmektedir (Aktepe, 2018). Bu zamana kadar yapılan çalışmalara bakıldığında ise aile katıımı ve aile eğitiminin; çocuğun gelişimini destekleme kendilik algısının ve benlik saygısının gelişimine katkı sağlama, akademik başarını arttırma, ailelerin kendilerini geliştirebilmeleri gibi konularda önemli role sahip olduklarını ve ailelerin çocukların eğitimine katılmalarının ne kadar gerekli olduğunu ortaya koymaktadır (Özcan ve Aydoğan, 2014).

Öğretmenlerin aile katılımının olduğu durumlarda çocukların okuma ve yazma becerilerindeki başarılarına ilişkin görüşleri değerlendirildiğinde öğretmenlerin büyük bir çoğunluğu ailelerin katılımı sayesinde öğrencilerin okuma ve yazma başarısının arttığının görüşünü bildirmiştir. Aile katılımının, tüm eğitim kademelerinde çocukların akademik başarıları üzerindeki etkileri en çok dikkat çeken ve tartışmasız şekilde kabul edilen bir gerçekliktir (Lindberg, 2017).

Öğretmenlerin çocuklarının okuma ve yazma becerilerini öğrenim süreçlerine etkin olarak katılmayan ailelere yönelik görüşleri değerlendirildiğinde öğretmenlerin sınıflarında çoğunlukla bu tarz öğrencilere sahip olduklarını ifade ettikleri görülmüştür. Ebeveynlerin aile katılımı engelleri arasında kendi okul yaşantılarında karşılaştıkları olumsuzluklar, ekonomik sıkıntılarının olması, okula ayırabilecekleri zamanın sınırlı olması, eğitim düzeylerinin düşük olması, karşılaştıkları olumsuz öğretmen tutumları, ev ve okul kültüründe yaşanan uyuşmazlıklar farklı araştırmalarda ifade edilmektedir (Çağdaş, Özel ve Konca 2016).

Öğretmenlerin aileleri etkin olarak katılmayan öğrencilerin durumları hakkında görüşleri değerlendirildiğinde öğrencilerin çevresiyle olan sosyal ilişkilerin oldukça zayıf olduğu belirtilmiştir. Ailenin önceliğinin farklı olması, eğitim düzeylerinin de düşük olması da aileleri etkin olarak katılmayan öğrencilerin gözlemlenen durumlarındandır. Ailenin ekonomik koşullar doğrultusunda yeri geldiğinde çocuklarını okula göndermemesi bu durumun en güçlü örneklerinden olmuştur. Ekonomik durumun zayıf olması çocukların okul dışında çalışma durumlarını etkilemekte ve sonucunda ailenin de desteği olmayan bir eğitim öğretim hayatı ortaya çıkmaktadır.

Öğretmenlerin aile katılımı olan çocukların durumları ile aileleri etkin katılım sağlamayan çocukların durumlarını karşılaştırmalı olarak değerlendirmeleri istenmiştir. Katılımcıların görüşlerine bakıldığında akademik başarı yönden çocukların aralarında fark oluştuğu görülmüştür. Akademik başarının tam anlamıyla sağlanmasında aile desteğinin önemi oldukça büyüktür. Aynı zamanda öğrencilerin kişisel gelişim yönünden de farklılıkları olduğu görülmüştür. Aileleri etkin katılım sağlayan öğrencilerin daha yüksek özgüvene sahip olduğu ortaya çıkmıştır. Ailelerin etkin katılımı, öğrencilerin sosyalleşmesi açısından da büyük etkiye sahip olduğu anlaşımıştır. Eğitim ve öğretim sürecinde aile ve okul arasında gerçekleşen etkili bir işbirliği ve karşıııklı etkileşimin, öğrencinin okul başarısına çok büyük katkıları vardır. Aile faktörü, öğrencilerin sosyal, duygusal, bilişsel ve psikomotor gelişimi ve akademik başarısını etkileyen en önemli faktörlerden biridir. Bu sebeple ailelerin eğitim ve öğretim sürecinde çocuklarının gelişini ve akademik başarısını yakından izlemesi ve okulda yapılan etkinliklere tüm samimiyetiyle katılması gerekmektedir (Hacısalihoğlu-Karadeniz, Aksu ve Topal, 2012).

Araştırmada öğrenciler arasında oluşan farklııkların aile katılımından kaynaklanmadığına ilişkin görüşleri değerlendirildiğinde öğretmenlerin büyük çoğunluğu bu farklılığın aile katılımından kaynaklandığını belirtmiştir. Aile uyumlu, iç ve dış düzenlenişi olağan, toplumdaki gelişmeler onun yapısını bozacak durumda değilse çocuk için mükemmel bir eğitim yuvasıdır. Ailenin eğitici nitelikte olan toplumsal çevresi, ailenin çocukları ile çeşitli hak ve sorumluluklarla birbirine bağlayan ideal bir eğitim ortamıdır (Ilgar ve Coşgun-Ilgar, 2018).

Araştırmada öğretmenlerin öğrencilerin okuma ve yazma becerilerindeki gelişimleri nasıl değerlendirdiklerine yönelik görüşleri göz önünde bulundurulduğunda değerlendirme çalışmaları olarak dikte çalışması, sınıf içi okuma, plan ve programa göre değerlendirmelerin yapıldığı görülmüştür. Okuma yarışmaları ve gözlem formları da kullanılan değerlendirme çalışmalarındandır. Etkili bir değerlendirme, söz konusu ölçme kriterleri göz önüne alınarak yapılır. Başarılı bir değerlendirme sadece test sorularıyla yapılmamalıdır. Farklı türde sorular ve ölçme yöntemleri ile değerlendirmeler gerçekleştirilmelidir (Akyol, 2007). 
Öğretmenlerin okuma ve yazma sürecine etkin katılan ailelerin çocuklar üzerinde baskı kurup kurmadıklarına yönelik görüşleri değerlendirildiğinde ailelerin çocuklar üzerinde baskılar oluşturduğu anlaşıımıştır. Ailenin etkin katılım göstermeleri ve çocuklarını iyi tanıyarak beklentilerini bu doğrultuda oluşturmaları baskıyı ortadan kaldıracağı öğretmen görüşleri doğrultusunda anlaşımıştır.

Çocuk ve ebeveyn arasında ev ortamında gerçekleşen okumanın bir çeşit aile katılımı olup olmadığı yönündeki öğretmen görüşleri değerlendirildiğinde öğretmenlerin hepsi nu tür bir okumanın aile katılımı olduğu yönde görüşlerini dile getirmişlerdir. Böylelikle ailelerin rol-model olma durumunu gerçekleştirdiğini, çocuğun teşvik edildiğini, ilgiyi daha çok hissettiği ve öğrenciye destek olunduğu yönünde durumu değerlendirmişlerdir. Böylece eğitimin sadece okulda sınıfı kalmadığı ve ailede de devam ettiği ortaya çıkmıştır. Aile katılımı etkinlikleri genel olarak ev ve okul temelli olmak üzere iki başlık altında toplanmıştır. Ev temelli aile katılım etkinlikleri; okul dışı uygulamaları içermekte ve bu uygulamalar çoğunlukla ev ortamında geçekleştiği için ev temelli olarak isimlendirilmiştir. Öğretmen tarafından ailelerin ve çocukların evde yapmaları önerilen etkinlikler önemli bir kısmı kapsamaktadır. Okul temelli etkinlikler ise ailelerin okul ile iletişimlerini, okul merkezli uygulamalarda yer almalarını kapsamaktadır (Kurtulmuş, 2016).

Öğretmen inançları ile ilgili görüşlerden elde edilen sonuçlar genel olarak değerlendirildiğinde öğretmenlerin bir kısmı aile katılımını çocuğa gösterilen ilgi olarak tanımlarken bir kısmı da aile ve öğrenci arasındaki iletişim olarak tanımlamıştır. Bir diğer kısım ise ailenin çocuğuna destek olması üzerine tanımlamasını gerçekleştirmiştir. Uygun aile katılımı öğretmen, aile ve öğrenci arasında iş birliğine dayandığını ve öğretmenin okulda öğrenciye olduğu rehber gibi ailenin de evde öğrenciye rehber olabilmesine dayandırımıştır. Aile katılımı ile aileler okulda yapılan etkinliklere ve planlamalara etkin bir şekilde katılma fırsatı yakalamış olurlar. Bu sebeple aileler okullarda yer verilen konulara hâkim olurlar. Çocuklarının eğitimi konusunda gerekli özellikleri edinir, sosyal ve duygusal destek alır, konunun uzmanı ile bilgi alışverişi yapmış olurlar (Ömeroğlu, Kandır ve Ersoy, 2003).

Diğer bir araştırma sonucu öğretmen görüşleri bağlamında ailelerin çocuklarının okuma ve yazma eğitim süreçlerine etkin bir şekilde katılmak istediklerini göstermiştir. Ancak bu durumu engelleyen farklı sebeplerin olduğu ifade edilmiştir. Aile katılımında çocukların eğitimlerinin desteklenmesi, ailelerin de eğitilmesi söz konusudur. Aile katılımının gerçekleşmesi ile ailelerin bazı bilgi ve becerileri edinerek çocuklarıyla olan iletişimlerini yararlı hale getirmeleri istenmektedir. Çocuklarının gelişim düzeyleri hakkında bilgiye sahip olan aileler, kendilerine daha çok güven duyarak çocuklarını daha iyi anlayıp, eksik yönlerini daha kolay bir biçimde telafi edeceklerdir (Çağdaş, Özel ve Konca, 2016).

Diğer bir araştırma sonucu öğretmen görüşlerine göre okulların aile katılımını artırmaya yönelik etkinlikler yaptığını göstermiştir. Yönetmelik gereği okullar, okul ve aile birliklerini kurmak ve işletmek zorundadırlar. Okulların eğitim ve öğretimde ailenin rolü, ailenin öğrenci başarısındaki etkisi, okulun yetki ve sorumlulukları konularında ailelerin okulla işbirliği yapıp yapmamalarını etkileyen önemli bir etkendir (Tümkaya, 2017).

Öğretmen inançları doğrultusunda diğer bir araştırma sonucu aile katılımının çocuğun okuma ve yazma başarısındaki önemini ortaya koymuştur. Ailelerin çocuğun eğitiminde izledikleri farklı tutumların, çocuklar üzerinde doğrudan ve dolaylı etkileri bulunmaktadır. Demokratik ailelerde yetişen çocukların izin verici ya da otoriter ailede yetişen çocuklardan akademik başarı, sosyal gelişim açısından daha üst seviyede oldukları görülmüştür. Aynı zamanda çocuklarına ilgili samimi davranan ailelerin çocuklarının, katı ve sıkı kontrol uygulayan ailelerin çocuklarına göre sosyal yeterlikleri ve daha olumlu sosyal davranışları sergiledikleri ortaya çıkmıştır (Yoleri ve Taşdelen-Karçkay, 2015). Ailesinin okul ile olan ilişkisinin yoğun ve samimi olduğunu bilen bir öğrenci, diğer öğrencilere göre daha sorumludur. Çünkü kendisiyle ilgili gelişmelerden ailesinin de haberi olacağının farkındadır. Çocuğun okul dışı çevresinin ve bu çevredeki gelişmelerin okula ve öğretmenlere yansıtılması, öğrencinin okul sürecinde daha net tanıtılmasına ve öğretmenlerin öğrenciyi tam olarak tanıyıp yaklaşmalarına, ölçmelerine ve değerlendirmelerine yardımcı olmaktadır (Ünlü, 2005). Aile katılımının tam anlamıyla gerçekleştirilebilmesi için ailenin eğitilerek çocukların okul başarılarını etkileyecek olumsuzlukları azaltmak, öğretimi etkili hale getirmek, ailelerin okula olan yabancılıklarını gidermek, ailelerin 
öğrenime katılımını sağlamak, ailenin çocuklarına ev ortamında edinebileceği bilgileri ve çocuklarııın yaşamlarındaki rollerinin gösterilmesi gerekmektedir (Çağdaş, Özel ve Konca, 2016).

Öğretmenlerin aile katılımını artırmak amacıyla kendilerinin etkili stratejiler kullanıp kullanmadıkları ile inançları değerlendirildiğinde katılımcılardan birçoğu etkili stratejiler uyguladıklarını ifade etmişlerdir. Çamlıbel ve Çakmak (2014) aile katıımının farklı şekillerde sağlanabileceğini; sınıfı ziyaret etmek, gönüllü öğretmen yardımcısı olmak, alan gezilerinde yardımcı olmak, çocuklara şarkı söylemek, şarkı öğretmek, hikâye okumak gibi sınıf içi etkinliklere katılmak, çocuklar için gerekli olan araç-gereçleri yapmak, kendi kültürüne özgü yöresel bilgiler sunan etkinlikler yapmak, (hikâye, şarkı, dans, yiyecek ya da kelime), kendi meslek ya da çalışma alanları hakkında bilgi vermek diğer ailelerle birlikte karşılıklı bilgi alışverişinde bulunmak diğer ailelere ulaşmada ve onlarında katılım sağlanmasında öğretmene yardımcı olmak, okulda yapılan bazı etkinlikleri evde de çocukla birlikte yapmak, sınıf içi etkinliklerde kesme, dikme ve onarma gerektiren materyallerde yardımcı olmak, sınıfa evcil bir hayvan getirmek gibi etkinliklerin aileler tarafından gerçekleştirilebileceğini belirtmişlerdir.

Öğretmen görüşlerine göre aileler, öğretmen ve okul personelinin yardımlarıyla çocuklarının eğitim sürecine kolayca dâhil olabilmektedirler. İstedikleri zaman yüz yüze veya telefonla görüşmelerin sağlanabileceği rahatlık her zaman verilmeye çalışılmaktadır. Yine öğretmen görüşlerine göre aileler kendilerini katılım noktasında çok fazla sorumlu hissetmemektedirler. Öğretmenlere göre aileler sorumluluğun öğretmende olması gerektiğini düşündüklerini dile getirmişlerdir.

\section{Kaynaklar}

Aktepe, V. (2018). ilkkokul 4. sınıf öğrencilerinin özgüvenlerinin bazı değişkenler açısından incelenmesi. Atatürk Üniversitesi Sosyal Bilimler Enstitüsü Dergisi, 22, 757- 772.

Akyol, H. (2007). Ilk okuma yazma öğretimi. Ankara: Pegem Akademi.

Atabey, D. ve Tezel Şahin, F. (2011). Aile öğretmen iletişim ve işbirliği ölçeği. Kastamonu Eğitim Dergisi, 19(3), 793-804.

Balcı, A. (2017). Sosyal medya temelli anne katılım programının anne çocuk ilişkisine ve anne öğretmen işbirliği-iletişimine etkisinin incelenmesi, (Yayımlanmamış Yüksek Lisans Tezi) Gazi Üniversitesi, Eğitim Bilimleri Enstitüsü: Ankara.

Balcı, A. ve Tezel-Şahin, F. (2018). Öğretmen-aile iletişiminde WhatsApp uygulamasının kullanımı. Gazi Üniversitesi Gazi Eğitim Fakültesi Dergisi, 38(2), 749-776.

Creswell, J.W. ve Miller, D.L. (2000). Determining validity in qualitative injury. Theory into Practice, 39, 124-130.

Çağdaş, A. ve Şahin Seçer, Z. (2011). Anne baba eğitimi. Ankara: Eğiten.

Çağdaş, A., Özel, E. ve Konca, A. S. (2016). İlkokul başlangııında velilerin aile katılım düzeylerinin incelenmesi. Eğitimde Kuram ve Uygulama Dergisi, 12(4), 891-908.

Çamlıbel-Çakmak, Ö. (2014). Okul öncesi eğitim kurumlarında aile katılımı. Abant izzet Baysal Üniversitesi Sosyal Bilimler Enstitüsü Dergisi, 10(1), 1-18.

Çelenk, S. (2003). Okul başarısının ön koşulu: Okul aile dayanışması. İlköğretim Online Dergisi, 2(2), 2834.

Gül, G. (2007). Okuryazarlık sürecinde aile katılımının rolü. Özel Eğitim Dergisi, 8(1), 17-32.

Güler, T. (2007). Okul öncesi eğitimde ailenin önemi ve okul aile işbirliği. Haktanır G. (Ed.), Okul öncesi eğitime giriş içinde (s. 295-322) Ankara: Anı Yayıncılık.

Hacısalihoğlu-Karadeniz, M., Aksu, H. H. ve Topal, T. (2012). Aile katılım sürecinin ilköğretim birinci kademe öğrencilerinin matematik başarısına yansımaları. Milli Eğitim Dergisi, 42(196), 232245.

Ilgar, M. Z. ve Coşkun Ilgar, S. (2018). Eğitime aile odaklı yaklaşmak. Uluslararası Toplumsal Bilimler Dergisi, 2(1), 22-49.

Keçeli-Kaysılı, B. (2008). Akademik başarının arttırılmasında aile katılımı. Ankara Üniversitesi Eğitim Bilimleri Fakültesi Özel Eğitim Dergisi, 9(1), 69-83.

Kurtulmuş, Z. (2016). Okul öncesi eğitimde uygulanan etkinlik planlarında aile katılımı boyutunun incelenmesi. Cumhuriyet Uluslararası Eğitim Dergisi, 5(1), 71-84. 
Linberg, E. N. (2017). Aile katılımı: bir kavramsal ve durumsal analiz çalışması. Uluslararası Eğitim Bilimleri Dergisi, 4(13), 51-72.

Oğuz, K. (2012). Ilköğretim okullarında aile katılımı: Ölçek uyarlama, (Yayımlanmamış Yüksek Lisans Tezi). Kastamonu Üniversitesi, Sosyal Bilimler Enstitüsü: Kastamonu.

Ömeroğlu, E. ve Can Yaşar, M. (2005). Okul öncesi eğitim kurumlarında ailenin eğitime katılımı. Bilim ve Aklın Aydınlığı Eğitim Dergisi. 2010-1(20), 1-17.

Özbaş, M. (2013). İlköğretim okulu yöneticilerinin ilköğretim birinci sınıf öğrenci ailelerinin okul yaşamına katılım eğitimi konusundaki görevlerine ilişkin veli algıları. Eğitim ve Bilim Dergisi, 38(170), 61-78.

Özcan, A. ve Özcan, A. (2016). İlk okuma yazma öğrenmede çocukların yaşadıkları güçlükler, nedenleri ve çözüm önerileri: Nitel bir araştırma. Istanbul Gelişim Üniversitesi Sosyal Bilimler Dergisi, 3(1), 69-103.

Özcan, Ç. ve Aydoğan, Y. (2014). Aile katılımı ile çocukların akademik benlik saygısı arasındaki ilişkinin anne-baba görüşlerine göre incelenmesi. Milli Eğitim Dergisi, 44(202), 19-36.

Özenç, E. (2007). Illk okuma ve yazma öğretiminde oyunla öğretim yöntemine ilişkin öğretmen görüşlerinin incelenmesi, (Yayımlanmamış Yüksek Lisans Tezi). Marmara Üniversitesi, Eğitim Bilimleri Enstitüsü: İstanbul.

Selanik Ay, T. ve Aydoğdu, B. (2016). Sınıf öğretmenlerinin aile katılımına yönelik görüşleri. Adıyaman Üniversitesi Sosyal Bilimler Enstitüsü Dergisi, 8(23), 562-590.

Şimşek, H. ve Tanaydın, D. (2002). Öğretmen ve veli katılımı: öğretmen-veli psikolojik danışma üçgeni, İlköğretim Online, 1(1), 12-16.

Tok, Ş., Tok, T. ve Mazı, A. (2008). Illk okuma yazma öğretiminde çözümleme ve ses Temelli cümle yöntemlerinin değerlendirilmesi. Kuram ve Uygulamada Eğitim Yönetimi Dergisi, 53, 123-144.

Tümkaya, S. (2017). Velilerin okulda eğitime katılım türlerinin bazı değişkenlere göre incelenmesi. Çukurova Üniversitesi Sosyal Bilimler Enstitüsü Dergisi, 26(2), 83-98.

Ünlü, H. (2005). Anne babalar için eğitim rehberi. İstanbul: Morpa Kültür Yayınları.

Ünüvar, P. (2010). Aile katılımı çalışmalarına yönelik ebeveyn ve öğretmen görüşlerinin karşılaştırılması. Kastamonu Eğitim Dergisi, 18(3), 719-730.

Yıldız, H. (2017). İlkokula devam eden özel gereksinimli çocuğa sahip ailelerin çocuklarının eğitimlerine katılımlarının incelenmesi. Türkiye Eğitim Dergisi, 2(2), 82-94.

Yoleri, S. ve Taşdelen Karçkay, A. (2015). Okul öncesi aile katıımının ebeveyn tutumlarını yordayıcı etkisi. Millli Eğitim Dergisi, 45(206), 121-134.

\section{Introduction}

\section{Extended Abstract}

From the point of view of academic and social development features, the first literacy process, which is one of the primary education activities in primary school, is one of the most important stages of primary education that constitutes the basic and compulsory education step. This phase should be managed with an effective approach in order for the student to act as a successful start to their learning experiences. One of the most important managerial activities to be held for this purpose is "providing family support to the first literacy teaching process." For this reason, "family education needs analysis" should be done for each family first. Because the effective support that families can provide to their children without knowing what educational advantages or disadvantaged situations they have is unknown. The "first literacy process", which constitutes the beginning of primary education, also forms the basis of primary, secondary and higher education. The first literacy process is a stage where functional literacy is tried to be acquired, as well as the qualifications that constitute the beginning of all educational experiences. The success of the first literacy process is based on full and continuous cooperation of the family with the school. Families whose children have just started primary education have to ensure their children's full-time participation in their schools, on the other hand, to constantly participate in educational and social activities in their school life. Effective family participation in the school can be achieved through the "family education" that schools will offer to families in accordance with student characteristics and needs. 


\section{Method}

In this study, it was aimed to evaluate the effective family participation of elementary school first grade students in the process of learning literacy skills through the eyes of their class teachers. In this context, the research was designed as a qualitative case study. In the research, fact science (phenomenology), one of the qualitative research methods, was used in accordance with the purpose. Qualitative research is an important research pattern in terms of ensuring that the incidents, facts and situations are revealed and their causes are determined as well as enabling the participants to be involved in the process (Ozcan \& Ozcan, 2016). The sample of the research consisted of 43 elementary school classroom teachers working in the province of Kars. Convenient sampling method was used in the study. Participation in the study is based on volunteering. Within the scope of the study, 60 classroom teachers were contacted. However, out of 60 classroom teachers, only 43 classroom teachers returned to the questionnaires. In the study, a questionnaire form consisting of open-ended questions developed by the researcher was used. During the development of the questionnaire, the relevant literature was examined and a draft form was structured with questions prepared in line with the information obtained. The draft form created was examined by experts, including the researcher. With the help of the relevant feedback, the questions were rearranged in terms of measurement, the purpose of the research, understanding, ordering and design. Then, a questionnaire was given to 5 classroom teachers outside the research group and the questionnaire was rearranged with the feedback from them. The questionnaire form consists of five parts. In the first part, questions regarding the demographic characteristics of the participants were included. The questions in this section gathered data on the participants' gender, age, professional experience, the location of the school where they work, the duration of the school in which they work, and the grade levels they have studied so far. In the second part of the questionnaire, data on the pre-lives of the participants were collected. In this section, a total of 5 open-ended questions are included. In the third part of the questionnaire, data were collected on the personal strategies and experiences of the parents regarding the plans they implemented for the family participation, the plans implemented by the school, and the parents' efforts towards family participation. In this context, a total of 16 open-ended questions were included in the third part of the questionnaire. In the fourth part of the questionnaire, data were collected on the opinions of the participants about their beliefs about family, family participation and the institution they work for. This section includes 13 open-ended questions in total. In the fifth chapter, which is the last part of the questionnaire, data were collected on the opinions of the participants regarding the recommendations they suggest to their colleagues for the effective participation of families. In this context, in the closing section, which is the last part of the questionnaire, a total of 1 open-ended question is included. The data obtained from the open-ended question were first transferred to the WORD Processor on the computer under each question title and analyzed separately by each researcher. Then, the encodings reached were compared. In cases where there are differences of opinion, the results were reevaluated together and consensus was achieved. Obtained codes are tabulated under the question heading related to the frequency of repetition. The frequency values in the tables showed not how many people but how many people did the coding express.

\section{Result and Discussion}

Descriptive analysis was employed on the obtained data. It was seen that family involvement was insufficient according to results obtained from findings of the research. It was found that the effect of the studies on family involvement was insufficient for the families. Expectations and priorities of parents were seen as the biggest effect of insufficient family involvement. It was observed that the differences between the students having family support and the other friends in the class were noticeable. It was come into agreement that first reading and writing process is not limited to school and it will be more useful to continue and integrate at home. 